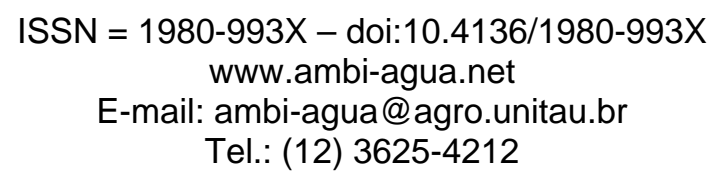

\title{
The burying behavior of the mole crabs before and after an accident with urban sewage efluents in Bombinhas Beach, Santa Catarina, Brazil
}

\author{
(http://dx.doi.org/10.4136/ambi-agua.627) \\ Vanner Boere'; Edison Rogério Cansi²; \\ Adriano Brasileiro Braga Alvarenga ${ }^{3}$; Ita de Oliveira e Silva ${ }^{4}$ \\ ${ }^{1}$ Department of Medicine and Nursing, Federal University of Viçosa, Viçosa, MG, Brazil \\ e-mail: vanner.boere@ufv.br; \\ ${ }^{2}$ Post-graduate Program in Animal Biology, University of Brasilia, DF, 70910-000 \\ e-mail: tiercansi@yahoo.com.br; \\ ${ }^{3}$ Post-graduate Program in Animal Science, University of Brasilia, DF, \\ e-mail: alvarenga@unb.br \\ ${ }^{4}$ Department of Animal Biology, Federal University of Viçosa, Viçosa, MG, Brazil \\ e-mail: ita.silva@ufv.br
}

\begin{abstract}
Several environmental factors may interfere in the behavior of mole crab (Emerita brasiliensis Schmitt, 1935), such as the discharge of urban pollutants on the shore, which can be toxic. During a study of the impact of human activities on a beach in Southern Brazil, opportunistically it was tested if burying behavior of the mole crab were affected after an accident causing the discharge of urban effluents. When comparing the period before (two days) and after (one day) the accident, there was a substantial increase in the concentration of ammonia in the seawater, but $\mathrm{pH}$, water temperature, salinity, and the microclimatic conditions remained stable. During the increased ammonia phase, we captured individuals of smaller size, but the latency in an burying test conducted in an aquarium, immediately after the capture, remained unaltered. The discharge of organic pollutants seems affected the surf zone, where small individuals were more abundant, supposedly males and juveniles but not adult females. The maintenance of burying latency by males and juveniles seems to suggest a greater physiological resistance to a short term contamination by ammonia.
\end{abstract}

Keywords: Burying; mole crab; Emerita brasiliensis; pollution effects; sewage.

\section{O comportamento de enterramento de tatuís antes e após um acidente com efluentes de esgoto urbano na praia de bombinhas, Santa Catarina, Brasil}

\section{RESUMO}

Muitos fatores ambientais podem interferir no comportamento dos tatuís (Emerita brasiliensis Schmitt, 1935) como os poluentes urbanos na orla, que podem ser tóxicos. Durante um estudo do impacto de atividades humanas sobre uma praia no sul do Brasil, observou-se de forma oportuna se o comportamento de enterramento dos tatuís foi alterado após a descarga de poluentes de esgoto urbano. Quando comparando os dois primeiros dias com o último dia de observações, a concentração de amônia na água do mar aumentou substancialmente, mas o $\mathrm{pH}$, a temperatura da água, a salinidade e as condições 
BOERE, V.; CANSI, E. R.; ALVARENGA, A. B. B.; SILVA, I. O. The burying behavior of the mole crabs before and after an accident with urban sewage efluents in Bombinhas Beach, Santa Catarina, Brazil. AmbiAgua, Taubaté, v. 6, n. 3, p. 70-76, 2011. (http://dx.doi.org/10.4136/ambi-agua.627)

microclimáticas permaneceram estáveis. Durante a fase de aumento da amônia capturaram -se indivíduos menores, mas a latência de enterramento testada em um aquário imediatamente após a captura permaneceu inalterada. A descarga de poluentes orgânicos parece afetar a zona de surfatação em que indivíduos menores foram mais abundantes, supostamente machos e juvenis, sem fêmeas adultas. A manutenção da latência de enterramento por machos e juvenis sugere uma resistência maior para uma contaminação de curto prazo de amônia.

Palavras-chave: enterramento; Tatuí; Emerita brasiliensis; efeitos de poluição; esgoto.

\section{INTRODUCTION}

Several factors may interfere in the behavior of mole crab such sediment characteristics (Defeo et al., 1997; Ribeiro et al., 2005), pollution (Lercari and Defeo, 1999; 2003), and human activities (Lercari and Defeo, 2003; Sauco et al., 2010). Some toxins such high ammonia concentration, present in the discharge of urban pollutants is among the most dramatic effects caused by human activities that modify the behavior and health of the intertidal macrofauna (Lercari and Defeo, 1999; Siemens et al., 2001).

A few species of crustaceans have been studied on coastal regions, especially in the surf zone, an unstable environment, propitious to the manifestation of several environmental stressors. The mole crab Emerita brasiliensis (Crustacea: Anomura: Hippidae), belongs to an intertidal faunal, presenting differentiated responses concurrent with the environmental variability in the spatial and temporal scales (Contreras et al., 1999; Lercari and Defeo, 1999). The mole crab can be found in several localities along the South Atlantic American coast, from Espírito Santo, Brazil, to the Uruguayan shore (Veloso and Cardoso, 1999).

The mole crab is an important resource in the food chain, in both reflexive and dissipative beaches (Rodgers, 1987; Lercari and Defeo, 1999; Hubbard and Dugan, 2003). This crustacean is used in a smaller scale by humans as a food source, and as bait in traditional fishing activities. The genus Emerita has been considered a potential bioindicator for chemical pollutants, mostly due to its physiological resistance, widespread distribution, easy capture, and proximity to coastal human activities (Pérez, 1999; Powell et al., 2002).

Escape and burying is a defensive, predator evasion and conservative energy behavior of crabs in general (McGaw, 2005). To understand the behavior of the mole crab in relation to the impact caused by human activities, especially recreational activities, we have been conducting a defense (escape and burying) behavior study of mole crab in the Southern Brazilian shore. During this semi-naturalistic behavioral study, we have observed the effects of an environmental accident, the rupture of an urban sewage effluent pipeline, which modified the sea water conditions in the study area.

This article reports the effects on burying behavior of mole crabs, under natural conditions without pollutants and after the accident that caused high regional impact in the biotic and abiotic aspects.

\section{MATERIAL AND METHODS}

The study was conducted on the urbanized Bombinhas beach, Santa Catarina, on the Southern coast of Brazil, during three consecutive days $\left(25^{\text {th }}\right.$ to $27^{\text {th }}$ of May 2005) between 14:00 $\mathrm{h}$ and 18:00 h. Bombinhas is a $1000 \mathrm{~m}$ long dissipative beach. Due logistic problems authors left the beach after the third day. The trials were conducted on the Southern end of the beach, at $100 \mathrm{~m}$ from the Sapo Creek estuary (S $27^{\circ} 08^{\prime}$ '904” and W 48 $29^{\prime}$ '049”).

The experimental procedure consisted of randomly collected samples from a $200 \mathrm{~m}^{2}$ quadrangular area, which was previously marked; its center was equally distant from the 
BOERE, V.; CANSI, E. R.; ALVARENGA, A. B. B.; SILVA, I. O. The burying behavior of the mole crabs before and after an accident with urban sewage efluents in Bombinhas Beach, Santa Catarina, Brazil. AmbiAgua, Taubaté, v. 6, n. 3, p. 70-76, 2011. (http://dx.doi.org/10.4136/ambi-agua.627)

breaking line throughout the four hours of sample collection. Approximately every 3 minutes, on the moment of water reflux, we carried out an excavation of $20 \mathrm{~cm}$ of sand, with a shovel. The contents collected with the shovel were immediately deposited on a sieve (mesh: $5 \mathrm{~mm}$; diameter: $53 \mathrm{~cm}$ ) and were gently washed with sea water. One of the researchers, wearing latex gloves, randomly collected one of the mole crab specimens restrained on the mesh, and placed it, with its caudal end pointing to the breaking line, in the center of a behavioral test aquarium. The escape and burying behavior test aquarium $(27,3 \times 17,2 \times 10,6 \mathrm{~cm})$, was made of dull plexiglass, and contained approximately $1 / 3$ of its total volume of sand and the remaining filled with sea water, which were both collected from the research area. The aquarium had painted markings that delimitated four quadrants of equal volume, each containing sand and water.

It was collected and tested 242 E. brasiliensis specimens during the three study days (76 on the first day - no accident; 101 on the second day - accident; and 65 on the third day - after accident). As for behavior, it was observed the burying latency (time between the releasing on the water surface of the aquarium, and the burying of more then $90 \%$ of the body under the sand). Immediately after each trial, the focal specimen was gently unburied and measured (lateral length, and the rostrum-caudal length of the carapace) with a precision caliper (Mitoyo, Brazil). After the biometric data was collected, the focal individual was placed with the remaining specimens in the sieve, and they were all released at the breaking line, approximately $30 \mathrm{~m}$ from the study area.

During the capture procedures, it was measured the conditions of the sea water from the study area and the aquarium. The environmental temperature was measured with a termohigrometer (Extech, China) and luminosity was measured with a luximeter (Extech, China), measurements were taken every $30 \mathrm{~min}$. Luminosity was measured two consecutive times during each moment. It was measured perpendicularly above the breaking line at $50 \mathrm{~cm}$, and $50 \mathrm{~cm}$ above the aquarium. The sea water from the study area and from the aquarium was measured with a water thermometer (Oregon Scientific, EUA) every $30 \mathrm{~min}$.

The aquarium and sea water salinity was measured three times with a densimeter (Instant Ocean, Marineland Labs, EUA), at the beginning (14:00 h), half way through (16:00 h), and at the end $(18: 00 \mathrm{~h})$ of the tests. During these same intervals, to access the $\mathrm{pH}$, and the ammonia concentration in the aquarium and sea water, we used marine aquarium kits ( $\mathrm{pH}$ Kit and $\mathrm{NH}_{3} \mathrm{Kit}$; Labcon Test, Brazil), used in aquiculture chemical essays (e. g., Logato et al., 2009) obtaining three samples with two consecutive measurements during each moment.

On the morning of the second study day, an urban sewage effluent pipeline ruptured near the margins of the Sapo creek, on the Southern end of the beach, close to the beginning of the beach's sand strip, at approximately $100 \mathrm{~m}$ from the experimental area. The accident and the area where it happened were detected due to the strong unpleasant odor in the sea water. The spill lasted between 12 and 24 hours, but it was not possible to estimate how much effluents were discharged. It was collected data on the day before, during (second day) and after the accident (third day). Each diary collection lasted 12 hours.

The climatic and chemical data each day were summed and then average to provide a average by day. These means were used in all subsequent analyses. Comparison across and between days analysis were made using Kruskal-Walis one-way analysis of variance and Mann-Whitney tests, respectively, because non-normality distribution of data. Correlationship between morphological data of mole crabs was a Spearman's rank order correlation coefficient. To compare if there were size differences in the mole crab captured among the three days, we used a Kruskal-Wallis non-parametric test on the rostrum-caudal length. Means of the latency of burying aquarium test each day, were analyzed using a Kruskal-Walis one-way analysis of variance and Mann-Whitney tests, respectively, because non-normality 
BOERE, V.; CANSI, E. R.; ALVARENGA, A. B. B.; SILVA, I. O. The burying behavior of the mole crabs before and after an accident with urban sewage efluents in Bombinhas Beach, Santa Catarina, Brazil. AmbiAgua, Taubaté, v. 6, n. 3, p. 70-76, 2011. (http://dx.doi.org/10.4136/ambi-agua.627)

distribution of data. Means are represented with Standard Error (mean $\pm \mathrm{SE}$ ). The significant level in the comparisons was $\mathrm{P} \leq 0,05$, with bicaudal distribution.

\section{RESULTS}

There was no significant difference in the microclimatic factors and sea water condition among the three study days, with one exception. The concentration of ammonia in the sea water $\left(\mathrm{N}=23, \mathrm{df}=2, \chi^{2}=19.42, \mathrm{P}=0.0001\right)$ and in the aquarium sea water $\left(\mathrm{N}=23, \mathrm{df}=2, \chi^{2}=\right.$ 19.42, $\mathrm{P}=0.0001$ ) were different among the three days (Figure 1). The concentration of ammonia in the sea water was significantly higher on the third day in relation to the first $(\mathrm{Z}=$ $-3.56, P=0.001)$ and to the second day $(Z=-3.87, P=0.001)$. As the concentration of ammonia in the sea water and in the aquarium sea water was identical, for analysis and discussion purposes they are considered as one variable.

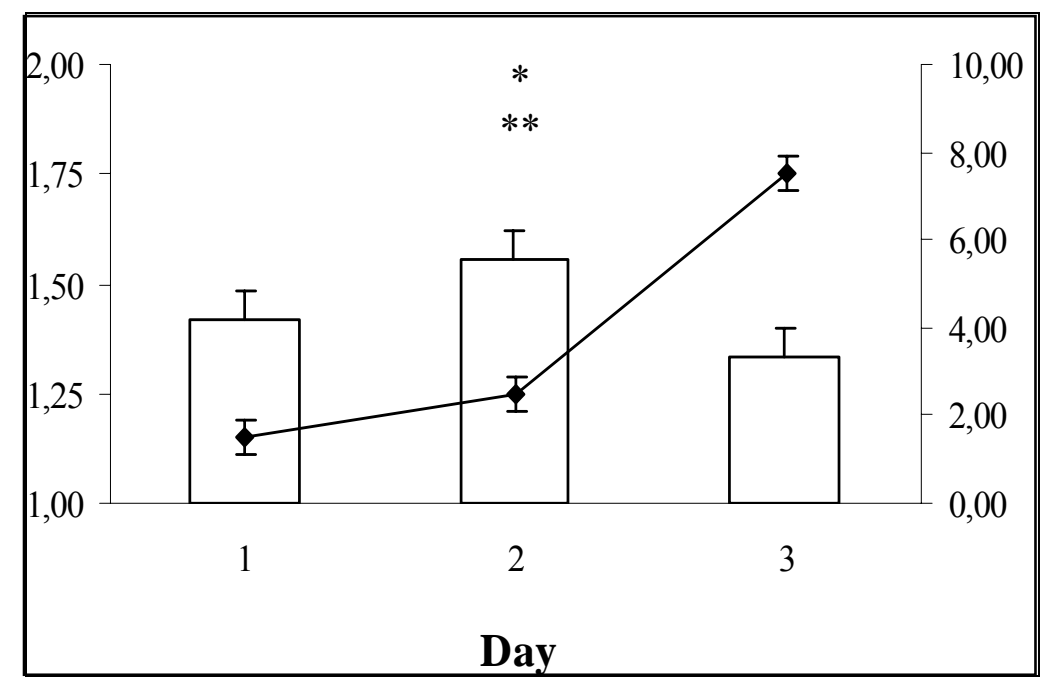

Figure 1: Comparative level of carapace length and ammonia concentration during the three study days, in Bombinhas beach. The values in the left axis of figure are millimeters and the bars are the lateral length mean. Values in the right axis are ppm-2 (part per million), and line is the mean of ammonia concentration. * represents differences of the carapace length of mole crabs between second day and third day $(\mathrm{P}=0.029)$; ** represents differences of ammonia concentration between of the third day and both, first and second days $(\mathrm{P}=0.001)$.

The mean lateral length and the mean rostrum-caudal length of the carapace of the mole crabs were highly correlated $(\mathrm{N}=239, \mathrm{r}=0.94, \mathrm{P}=0.001)$. As in other studies (Lercari and Defeo, 1999), we used only the lateral length as a morphometric data for analysis (Figure 1). There was a tendency to capture mole crabs of different sizes among the three days $(\mathrm{N}=239$, $\left.\mathrm{df}=2, \quad \chi^{2}=5.17, \mathrm{P}=0.075\right)$. Mole crabs captured on the third day were smaller (mean $=1.33 \pm 0.75 \mathrm{~mm}$ ) than the mole crab captured on the second day (mean $=1.55 \pm 0.82 \mathrm{~mm}$ ) $(\mathrm{Z}=-2.178, \mathrm{P}=0.029)$, but there were no differences between the captured specimens of the first day (mean $=1.45 \pm 0.79 \mathrm{~mm}$ ) in relation to the other two days (day 1 vs. day $2, \mathrm{P}=0.15$; day 1 vs. day $3, \mathrm{P}=0.39)$.

In spite of the size of mole crabs and differences of the ammonia concentration in the sea differences, there were no differences in the burying latency of mole crab among the three test days (mean $=6.58 \pm 9.91 \mathrm{~s} ; \mathrm{N}=239, \mathrm{df}=2, \chi^{2}=3,53, \mathrm{P}=0.17$ ). 
BOERE, V.; CANSI, E. R.; ALVARENGA, A. B. B.; SILVA, I. O. The burying behavior of the mole crabs before and after an accident with urban sewage efluents in Bombinhas Beach, Santa Catarina, Brazil. AmbiAgua, Taubaté, v. 6, n. 3, p. 70-76, 2011. (http://dx.doi.org/10.4136/ambi-agua.627)

\section{DISCUSSION AND CONCLUSION}

The size of the captured specimens seemed to have been affected by the levels of ammonia in the sea water, throughout the study period. On the other side, there were no changes in the burying latency in relation to different days and the changes in ammonia concentration.

The acceptable ammonia concentration for most fishes and crustaceans is around 0.4 ppm (United States of Environmental Protection Agency, 1989). On the third day, the ammonia concentration in the sea water reached $0.8 \mathrm{ppm}$, an extremely toxic level for most marine fishes and crustaceans. The concentration of ammonia in the water is one of the main environmental problems faced by marine organisms (Koo et al., 2005; Neil et al., 2005), affecting their osmoregulation metabolism by raising the competition with potassium ion in membrane of osmoregulatory gills (Weihrauch et al., 2004). Although it was not possible to conduct pathological analyses to the determination of lesions in gills in the captured specimens, the burying latency did not seem to be affected in the mole crabs captured in the third day. Meanwhile, there was a substantial difference in the size of these captured individuals. The smaller size of captured individuals of the third day suggests that males or juveniles were the sex-age class remaining on the beach. Reproductive females are bigger than juveniles or males and have more mobility than latter (Faulkes and Paul, 1997). Crustaceans are relatively resistant to high ammonia concentrations (Zhao et al., 1998) and mole crabs apparently are less fragile to survive in urban beaches (Veloso et al., 2010). Mature females, described as substantially larger (Petracco, 2003) might have been affected by the high concentrations of ammonia. A possibility is that females could have remained in deeper environments, where the concentrations of ammonia would be more diluted in relation to the volume of sea water. A set of more robust pereiopods in females than males and juveniles allows them to be relatively more independent in undertaking migrations from shallow areas to deeper regions of the coast (Faulkes and Paul, 1997).

The effect of higher ammonia concentration in mole crabs was either sex or age specific. The remaining specimens in the area still carried out escape and burying behavior in similar times than the previous days, with no pollution. Studies with macroinfauna, its habitat, and the impact caused by environmental stressors, such as pollutants, deserve more attention in coastal areas with few studies, as is the case of the South American Atlantic coast. The opportunity to study the effects of a sanitary accident on crustaceans in a natural environment, and its publication is rare in an area so deprived of scientific papers dealing with animal behavior.

\section{REFERENCES}

CONTRERAS, H.; DEFEO, O.; JARAMILLO E. Life history of Emerita analoga (STIMPSON) (Anomura, Hippidae) in a sandy beach of south central Chile. Estuarine Coastal Shelf Sciences, v. 48, p. 101-112, 1999.

http://dx.doi.org/10.1006/ecss.1998.0396

DEFEO, O.; BRAZEIRO, A; DE ALAVA, A.; RIESTRA, G. Is sandy beach macrofauna only physically controlled? Role of substrate and competition in Isopods. Estuarine Coastal Shelf Sciences, v. 45, p. 433-462, 1997. http://dx.doi.org/10.1006/ecss.1996.0200

FAULKES, Z.; PAUL, D.H. Digging in sand crabs (Decapoda, Anomura, Hippoidea): interleg coordination. Journal of Experimental Biology, v. 200, p. 793-805, 1997. 
BOERE, V.; CANSI, E. R.; ALVARENGA, A. B. B.; SILVA, I. O. The burying behavior of the mole crabs before and after an accident with urban sewage efluents in Bombinhas Beach, Santa Catarina, Brazil. AmbiAgua, Taubaté, v. 6, n. 3, p. 70-76, 2011. (http://dx.doi.org/10.4136/ambi-agua.627)

Hubbard, D. M.; Dugan, J. E. Shorebird use of an exposed sandy beach in southern California. Estuarine Coastal Shelf Sciences, v. 58S, p. 41-54, 2003. http://dx.doi.org/10.1016/S0272-7714(03)00048-9

KOO, J-G.; KIM, S-G.; JEE, J-H.; KIM, J-M.; BAI, S. C.; KANG, J-C. Effects of ammonia and nitrite on survival, growth and moulting in juvenile tiger crab, Orithyia sinica (LINNAEUS). Aquaculture Research, v. 36, p. 79-85, 2005. http://dx.doi.org/10.1111/j.1365-2109.2004.01187.x

LERCARI, D.; DEFEO, O. Effects of freshwater discharge in sandy beach populations: the mole crab Emerita brasiliensis in Uruguay. Estuarine Coastal Shelf Sciences, v. 49, p. 457-468, 1999. http://dx.doi.org/10.1006/ecss.1999.0521

LERCARI, D.; DEFEO, O. Variation of a sandy beach macrobenthic community along a human-induced environmental gradient. Estuarine Coastal Shelf Sciences, v. 58S, p. 17-24, 2003. http://dx.doi.org/10.1016/S0272-7714(03)00043-X

LOGATO, P.V. R.; ALBERNAZ, N. S.; RIBEIRO, P. A. P.; FREITAS, R. T. F.; FIALHO, E. T. Effect of the ration processing on the apparent digestibility values of nutrients for the piau (Leporinus elongatus). Ciência e Agrotecnologia, v. 33, n. 3, p. 890-894, 2009. http://dx.doi.org/10.1590/S1413-70542009000300032

MCGAW, I. Burying behaviour of two sympatric crab species: Cancer magister and Cancer productus. Scientia Marina, v. 69, n. 3, p. 375-381, 2005.

NEIL, L. I.; FOTEDAR, R.; SHELLEY, C. C. Effects of acute and chronic toxicity of unionized ammonia on mud crab, Scylla serrata (FORSKÅL, 1755) larvae. Aquaculture Research, v. 36, p. 927-932, 2005. http://dx.doi.org/10.1111/j.13652109.2005.01304.x

PÉREZ, D. Mercury levels in mole crabs Hippa cubensis, Emerita brasiliensis, E. portoricensis, and Lepidopa richmondi (Crustacea: Decapoda: Hippidae) from a Sandy Beach at Venezuela. Bulletin of Environmental Contamination and Toxicology, v. 63, p. 320-326, 1999. http://dx.doi.org/10.1007/s001289900983

PETRACCO, M., VELOSO, V. G., CARDOSO, R. S. Population dynamics and secondary production of Emerita brasiliensis (Crustacea: Hippidae) at Prainha beach, Brazil. Marine Ecology, v.24, n.3, p.231-245. 2003. http://dx.doi.org/10.1046/j.01739565.2003.00837.x

POWELL, C. L.; FERDIN, M. E.; BUSMAN, M.; KVITEK, R. G.; DOUCETTE, G. J. Development of a protocol for determination of domoic acid in the sand crab (Emerita analoga): a possible new indicator species. Toxicon, v. 40, p. 485-492, 2002. http://dx.doi.org/10.1016/S0041-0101(01)00236-7

RIBEIRO, P. D.; IRIBARNE, O. O.; DALEO, P. The relative importance of substratum characteristics and recruitment in determining the spatial distribution of fiddler crab Uca uruguayensis NOBILI. Journal of Experimental Marine Biology and Ecology, v. 314, p. 99-111, 2005. http://dx.doi.org/10.1016/j.jembe.2004.09.014

RODGERS, J. A. The foraging behavior of Gray Gulls at a sandy beach. Wilson Bulletin, v. 99, n. 2, p. 271-273, 1987. 
BOERE, V.; CANSI, E. R.; ALVARENGA, A. B. B.; SILVA, I. O. The burying behavior of the mole crabs before and after an accident with urban sewage efluents in Bombinhas Beach, Santa Catarina, Brazil. AmbiAgua, Taubaté, v. 6, n. 3, p. 70-76, 2011. (http://dx.doi.org/10.4136/ambi-agua.627)

SAUCO, S.; EGUREN, G.; HEINZEN, H.; DEFEO, O. Effects of herbicides and freshwater discharge on water chemistry, toxicity and benthos in a Uruguayan sandy beach. Marine Environmental Research. v. 70, n. 3-4, p. 300-307, 2010. http://dx.doi.org/10.1016/j.marenvres.2010.06.002

SIEMENS, R. A.; MUDGE, S. M.; CANCINO, J. M. The effect of physical and chemical parameters on the macroinfaunal community structure of San Vicente bay, Chile. Revista Chilena Historia Natural, v. 74, n. 2, p. 1-22, 2001. http://dx.doi.org/10.4067/S0716-078X2001000200017

UNITED STATES OF ENVIRONMENTAL PROTECTION AGENCY. Ambient aquatic life water quality criteria for Ammonia (Sea Water). Washington, D.C., 1989. 67 p.

VELOSO, V. G.; CARDOSO, R. S. Population biology of the mole crab Emerita brasiliensis (Decapoda: Hippidae) at Urca beach. Brazilian Journal Crustacean Biology, v. 19, p. 147-153, 1999. http://dx.doi.org/10.2307/1549556

VEloso, V. G.; SAllorenzO, I. A.; FERREIRA, B. C. A.; SOUZA, G. N. Atlantorchestoidea brasiliensis (Crustacea: Amphipoda) as an indicator of disturbance caused by urbanization of a beach ecosystem. Brazilian Journal of Oceanograph. v. 58, n. 1, p. 13-21, 2010. http://dx.doi.org/10.1590/S1679-87592010000100002

WEIHRAUCH, D.; MORRIS, S.; TOWLE, D. W. Ammonia excretion in aquatic and terrestrial crabs. The Journal of Experimental Biology, v. 207, p. 4491-4509, 2004. http://dx.doi.org/10.1242/jeb.01308

ZHAO, J. H.; GUO, J. Y.; LAM, T. J. Lethal doses of ammonia on the late stage larvae of Chinese mitten handed crab, Eriocheir sinensis (H.MILNE EDWARDS), (Decapoda: Grapsidae) reared in the laboratory. Aquaculture Research, v. 29, n. 9, p. 635-642, 1998. http://dx.doi.org/10.1046/j.1365-2109.1998.00253.x 